\title{
ANALYZING THE SERVICE DELIVERY OF KMF NANDINI AN EMPIRICAL STUDY
}

Dr.M.S.Ramachandra* Dr.G.Madegouda **

\begin{abstract}
The study concentrates on researching the service delivery of KMF Nandini.The study covered the geographical areas of Karnataka Co-operative Milk Producers Federation (KMF) which includes the cities of Bangalore, Mysore, Mandya, Kolar,Shimoga,Dharwar and Tumkur.The Study will concentrate primarily on the KMF based milk unions. The empirical paper attempts to identify the perceptions of consumers towards service delivery of KMF Nandini. The paper tries to identify the gaps between consumer expectations and the actual delivery of KMF Nandini.
\end{abstract}

\section{Introduction}

In India, dairying is recognized as an instrument for social and economic development. The nation's milk supply comes from millions of small producers, dispersed throughout the rural areas. These farmers maintain an average herd of one or two milch animals, comprising cows and/or buffaloes. The animals' nutritional requirements are largely met by agricultural waste and byproducts (Gupta, 1987). Ample labor and a small land base encourage farmers to practice dairying as an occupation subsidiary to agriculture. While income from crop production is seasonal, dairying provides a stable, year-round income, which is an important economic incentive for the small farmer to take to dairying.

Milk production in India is dominated by small and marginal landholding farmers and by landless labourers who, in aggregate, own about 70 percent of the national milch animal herd (Gupta, 1983). As crop production on 78 percent of the agricultural land still depends on rain, it is prone to both drought and floods, rendering agricultural income uncertain for most farmers. Shackled to subsistence production as a result of a shortage of finance and credit facilities, these farmers become entangled in a strangling debt cycle. The combination of an unfavourable land: person ratio and fragmented landholdings makes it difficult to support large families on crop income alone.

The successful Indian dairy development programme Operation Flood has shown how food aid can be used as an investment in building the type of institutional infrastructure that can bring about national dairy development. Programmes like Operation Flood, with similar policy orientations,

* Director Corporate Relations and institutional affairs, Dayanada Sagar Institutions, Bangalore

** Prof. and Dean, Department of Commerce, Kuvempu University, Shimoga 
may prove to be appropriate to dairy development in other Asian as well as African countries since the conditions that prevail in dairying today in a number of developing countries are comparable to those that once were found in India. In the early 1950s, India was commercially importing around 55000 tones of milk powder annually to meet the urban milk demand. Currently, many developing countries either commercially import dairy products on a large scale or rely on donations to meet the gap between demand and supply of milk products. Together, developing country imports account for over 70 percent of total world trade in milk products (FAO, 1993)

\section{Indian Diary Market}

The introduction of modern process technologies for the large scale production of Indian milk products, including mithais, has provided an opportunity to the organized dairy sector to expand its market and ensure financial stability and steady growth. This development is also having a tricked-down effect on the entrepreneurs in the traditional dairy sector who are modernizing their age-old mithai-making methods and coming out with new product formulations. The traditional dairy products sector will play a vital role in value-added utilization of rapidly increasing milk production in the country.

Despite the widespread popularity and acceptability of traditional milk products in the Indian milieu, the organized sector has still not been able to fully tap their market potential for many reasons. Some of the most important ones are:

(a) Inadequacy of appropriate technologies for their large-scale production;

(b) Inadequacy of appropriate packaging systems and labeling to take care of new patterns in consumer demand;

(c) Inadequacy of quality assurance systems in fulfilling the latest standards of hygiene and product safety; and

(d) Inadequacy of market intelligence to understand the mind-set of prospective entrepreneurs and inspire confidence in them to undertake commercial production of these products.

The organized dairy sector has so far not been able to take the full advantage of these products, as its current marketing systems do not permit the efficient distribution of short-shelf life products. The traditional milk products sector has the potential of emerging as a well-structured segment of the dairy industry. Recently, a few organized dairies have started production of some of the commercially important dairy products on a large scale, but their impact has been limited. Organized production and marketing would permit efficient distribution of these products to meet the needs of the consumers as well as ensure higher returns to rural milk produces in rural areas. 
Production and marketing of traditional milk sweets is mostly a small-scale and scattered affair confined to the 'halwa' shops in the local market. One reason for this is their short shelf life. The traditional sweets sector, which absorbs substantial proportion of milk production, has received little attention due to its concentration in the non-organized sector. Only some selective attempts have been made in the past to understand different dimensions of this sector, viz., raw material use, product portfolio, marketing tactics, etc. At the same time, relevant projections regarding this sector have so far proved a difficult talk in view of its structure and spread.

Milk Consumption Pattern: An estimated 54 per cent of India's milk production is converted into products, both traditional and western. In this, the share of traditional products is about 50 per cent, accounting in $\mathbf{2 0 0 1}$ for a little over $\mathbf{4 2}$ million tones of milk that yields over 10 million tones of mithais and other related products per year. The growth projections of their demand in the organized sector are presented in Table 1.

Table 1: Milk Consumption Pattern

\begin{tabular}{|c|c|c|}
\hline Product & Demand 1988 & Projected demand 2009 \\
\hline Ghee & 100000 & 200000 \\
\hline Cheese & 4200 & 15000 \\
\hline Paneer & 1000 & 16000 \\
\hline Shrikhand & 3000 & 5650 \\
\hline Rasogolla & 1600 & 6000 \\
\hline Gulabjamun & 3000 & 5850 \\
\hline
\end{tabular}

Source : Dairy India 2007

As the total expenditure on milk and milk products rises, consumers tend to spend proportionately less on liquid milk, ghee and butter and more on other milk products which include milk-based sweets, curds, paneer, ghee, butter etc.

Undoubtedly, the major challenge for the dairy sector in any developing nation is to increase milk production in order to meet the increasing demand resulting from the almost inevitable expansion of population and, presumably, growth of income. To meet this challenge, policies must become more market-oriented. The adoption of appropriate technologies for production, procurement, processing and marketing - after the unique environmental, social, economic, political and cultural environment of the individual country has been considered - is an important aspect of dairy development. Those national governments and international institutions for which the dairy sector is a major concern should accept the challenge and formulate policies that integrate and buttress the major functions of dairy development. 


\section{The Karnataka Co-operative Milk Producers Federation (KMF)}

The Karnataka Co-operative Milk Producers Federation (KMF) on its part, which was formed during the early 1980s, has taken tremendous strides in its operations all over the States of Karnataka .The Federation has now established 13 Milk Unions, which cater to almost 35 per cent of the population of Karnataka, through its Milk Unions dotted in the major cities of Karnataka. Over the last two decades, the KMF has met with a good degree of success in marketing its brand of Milk and Milk Products all over the state. However, the federation faces several problems which are directly affecting further growth. The financial performance of a majority of the Milk Unions is a matter of worry for the KMF's top management, which is now striving hard to see the turnaround of all the Unions is showing dismal financial performance figures. The federation has been trying out several ways of utilizing the excess milk inflow. It has been continuously trying out on creating value adding products like Skimmed Milk Powder, Butter, Ghee, Pedas, Buttermilk, Flavored Milk, Ice Creams, Badaam Powder, Cheese, and even Mysore Pak. These efforts have never been so heightened in the recent past as could be observed by the hectic marketing efforts of the KMF in appointing several wholesalers, retailers, and even franchises and vending booths to sell these products. Unfortunately, all these efforts have not yielded the desired results, in-as- much as the efforts of the Dairy Industry has not been met with an either equal match of even a sublimal match considering the enormity of production. There are several inherent bottlenecks in the system of distribution and promotion of the products.

This study intends to provide feedback of service delivery for KMF Nandini.

\section{Objectives of the Study}

1. To analyze the performance of K.M.F- with special reference to its service delivery;

2. To find out the customer perceptions towards KMF Nandini

\section{Scope of the Study}

The study concentrates on researching the service delivery of KMF Nandini. The study will cover the geographical areas of Karnataka Co-operative Milk Producers Federation (KMF) which includes the cities of Bangalore, Mysore, Mandya, Kolar,Shimoga,Dharwar and Tumkur. The Study will concentrate primarily on the KMF based milk unions. These Seven Milk Unions situated in the above cities are fairly representative of the KMF operations, and hence, the Study will primarily be restricted to these Unions with particular reference to service delivery, brand loyalty and customer segments. 


\section{Research design}

The study is one of a management problem at top echelons, but related to strategising its operations from the grass roots. In a way, this Study will have multifarious ramifications in reaching the desired Research objectives and there by has to be studied in a wider angle. Hence, the sampling plan consisted of researching 100 respondents in each of the 6 target markets of Mysore, Mandya, Kolar,Shimoga,Dharwar and Tumkur and 200 respondents in Bangalore city selected for Research purpose in the consumer category, making the total sample to 800 . The data collected is analyzed with the help of appropriate statistical tools and techniques for arriving at the accurate findings and conclusions.

\section{Results and discussions}

\section{Identifying factors of service delivery}

An important question before the researcher was to identify the factors on which the variables can be measured. Factor analysis can assist to identify the underlying factors that define the service delivery of a company. Factor analysis is useful in yielding easily understandable factors that convey the essential information contained in the original set of variables. Thus it was decided to use factor analysis in the present study. The "principal component analysis" and varimax rotation has been employed for the purpose of extraction and rotation of factors respectively. A total of 6 factors emerged from the factor analysis.

\section{KMO and Bartlett's test of sampling adequacy}

The Kaiser Meyer Olkin measure of sampling adequacy was used assess the appropriateness of factor analysis. Table gives the statistics produced by the variables.

\section{Table 2: KMO and Bartlett's Test}

\begin{tabular}{|l|l|l|}
\hline \multicolumn{2}{|c|}{ Kaiser-Meyer-Olkin Measure of Sampling Adequacy. } & .926 \\
\hline Bartlett's Test of Sphericity & Approx. Chi-Square & 24965.166 \\
\hline & $\mathrm{df}$ & 630 \\
\hline & Sig. & .000 \\
\hline
\end{tabular}

The KMO value is .926 and this is considered to be adequate to proceed with factor analysis of the data. This indicates that there is a high presence of correlation amongst the variables. The Bartlett's test of sphericity is 24965.1 , which is high value, and it is significant at .01 levels. So factor analysis would provide statistically reliable information. 
In table below the information containing all six possible factors and their factor loadings are featured. After rotation majority of the variance is explained by factor 1 and thereafter the following 5 factors increase only by a small percentage of variance explained.

\section{Factor 1- Customer service}

Factor 1accounts for $33.371 \%$ of the variance. The factor is made up of 14 variables that had highest loadings. These variables relate to customer related issues.

\section{Factor 2 Brand Image.}

Factor 2 accounts for $7.037 \%$ of the variance. The factor is made of 2 variables that relate to brand equity of the company.

\section{Factor 3-Accessibility and Availability}

This factor consists of 6 -varaibles of high factors loading. Factor 3 accounts for $4.777 \%$ of the variance.

\section{Factor: 4- Prices and offers}

Factor 4 accounts for $4.086 \%$ of the variance. Prices and offers make up this factor.

\section{Factor 5: quality of product and services}

Factor 5 accounts for $3.527 \%$ of the variance. This factor consists of 4 variables that are related to quality of the product.

\section{Factor 6- Tangibles}

Factor 6 accounts for $3.104 \%$ of the variance. This factor includes 4 variables that relate to physical appearance of the outlets.

Table 3: Factor analysis of service delivery aspects of KMF Nandini

\begin{tabular}{|l|c|c|c|c|c|c|}
\hline Factor 1: Customer service & 1 & $\mathbf{2}$ & $\mathbf{3}$ & $\mathbf{4}$ & $\mathbf{5}$ & $\mathbf{6}$ \\
\hline Providing quick service delivery & .612 & & & & & \\
\hline Dependability of service & .569 & & & & & \\
\hline $\begin{array}{l}\text { Providing clear and precise } \\
\text { information about products by } \\
\text { retailer }\end{array}$ & .653 & & & & & \\
\hline $\begin{array}{l}\text { Quickly responds to special } \\
\text { requests and orders }\end{array}$ & .617 & -.453 & & & & \\
\hline $\begin{array}{l}\text { Remembers previous problems } \\
\text { with the products }\end{array}$ & .574 & -.403 & & & & \\
\hline
\end{tabular}




\begin{tabular}{|c|c|c|c|c|c|c|}
\hline Factor 1: Customer service & 1 & 2 & 3 & 4 & 5 & 6 \\
\hline Returns the balance properly & .583 & -.304 & & & & \\
\hline Pays attention to Individuals & .389 & .378 & & & & \\
\hline $\begin{array}{l}\text { Employees' approachability and } \\
\text { willingness to help customers }\end{array}$ & .537 & & & & & \\
\hline $\begin{array}{l}\text { Attends to Physically } \\
\text { Challenged persons and } \\
\text { Senior Citizens }\end{array}$ & .588 & & & & & \\
\hline $\begin{array}{l}\text { Making the effort to understand } \\
\text { the needs and expectations of } \\
\text { customers }\end{array}$ & .439 & & & & & \\
\hline $\begin{array}{l}\text { Responsive and sensitive to } \\
\text { customer complaints, } \\
\text { suggestions and problems }\end{array}$ & .560 & & .305 & & & \\
\hline $\begin{array}{l}\text { Willingness to explain details } \\
\text { and clarify doubts about its } \\
\text { products }\end{array}$ & .537 & & & & & \\
\hline $\begin{array}{l}\text { Readily approachable I } \\
\text { available by customers }\end{array}$ & & & .419 & & & \\
\hline \multicolumn{7}{|l|}{ Factor 2 Brand image } \\
\hline $\begin{array}{l}\text { No of Years of existence in } \\
\text { business }\end{array}$ & & .589 & .403 & & & \\
\hline $\begin{array}{l}\text { Good will of the outlet } \\
\text { (Brand equity) }\end{array}$ & & .640 & .347 & & & .325 \\
\hline \multicolumn{7}{|l|}{$\begin{array}{l}\text { Factor } 3 \text { Accessibility and } \\
\text { Availability }\end{array}$} \\
\hline $\begin{array}{l}\text { Convenient time of product } \\
\text { supply }\end{array}$ & & & .604 & .464 & & \\
\hline Availability on all days & & & .600 & .458 & & \\
\hline Immediate availability & & .464 & .573 & & & \\
\hline
\end{tabular}




\begin{tabular}{|c|c|c|c|c|c|c|}
\hline $\begin{array}{l}\text { Factor } 3 \text { Accessibility \& } \\
\text { Availability }\end{array}$ & 1 & 2 & 3 & 4 & 5 & 6 \\
\hline Proximity to store outlet & & & .537 & & .419 & \\
\hline Home delivery & & & .588 & & & \\
\hline Timely supply & & & .439 & & .305 & \\
\hline $\begin{array}{l}\text { Availability of products in one } \\
\text { roof }\end{array}$ & & & .647 & & & \\
\hline Range of products under one & & & .621 & & & \\
\hline \multicolumn{7}{|l|}{ Factor 4 Prices and offers } \\
\hline Competitive prices & & & & 627 & & .580 \\
\hline $\begin{array}{l}\text { Concessional and discounted } \\
\text { fares for bulk purchases }\end{array}$ & & & & .710 & & \\
\hline $\begin{array}{l}\text { Providing rebates for regular } \\
\text { purchasers }\end{array}$ & & & & .623 & & -.325 \\
\hline Festiva; offers and packages & & & & .679 & & -.347 \\
\hline \multicolumn{7}{|l|}{$\begin{array}{l}\text { Factor } 5: \text { Quality of } \\
\text { product and services }\end{array}$} \\
\hline Good Quality (taste) & & & & & .633 & \\
\hline Good Quality (no storage) & & & & & .643 & \\
\hline $\begin{array}{l}\text { Product packing and } \\
\text { presentation }\end{array}$ & & & & & .596 & \\
\hline $\begin{array}{l}\text { Product labeling statutory } \\
\text { information }\end{array}$ & & & & .502 & .641 & \\
\hline \multicolumn{7}{|l|}{ Factor 6 : Tangibles } \\
\hline $\begin{array}{l}\text { Sign Board and other signages } \\
\text { written properly }\end{array}$ & & & .336 & & & .541 \\
\hline Merchandising and display & & .356 & & & & .649 \\
\hline $\begin{array}{l}\text { Seating arrangement at the } \\
\text { shops }\end{array}$ & & .243 & & & .359 & .623 \\
\hline General maintenance of shops & & & & & & .595 \\
\hline
\end{tabular}

Extraction Method: Principal Component Analysis 


\section{Analyzing service delivery factors}

The analysis of the factors by mean scores suggests that the expectations for all the factors are higher than the delivery (Table 4). Quality of product and services are the most expected factors by the customers, followed by accessibility and availability. All other factors are given due importance with scores above 3.50. The actual delivery of KMF is slightly below expectations with quality and accessibility being rated higher than other factors. The difference between the expectations and delivery were evident and statistically tested by paired sample tests.

As can be seen from the tables the gap is higher for tangibles and prices and offers suggesting company can look into the matter of designing the outlets more effectively.

Table 4: Analyzing the factors to find the service delivery gaps

\begin{tabular}{|l|l|l|l|l|}
\hline & \multicolumn{2}{|l|}{ EXPECTATIONS } & \multicolumn{2}{l|}{ EXPECTATIONS } \\
\hline FACTORS & MEAN & STD. DEVIATION & MEAN & STD. DEVIATION \\
\hline Customer service & 3.76 & .654 & 3.59 & .623 \\
\hline Brand image & 3.82 & .816 & 3.72 & 1.462 \\
\hline Accessibility and Availability & 3.97 & .823 & 3.82 & .766 \\
\hline Prices and offers & 3.65 & 1.359 & 3.43 & .924 \\
\hline Quality of product and services & 4.08 & .725 & 3.91 & .763 \\
\hline Tangibles & 3.81 & .917 & 3.52 & .767 \\
\hline
\end{tabular}

Figure 1: Analyzing the factors to find the service delivery gaps

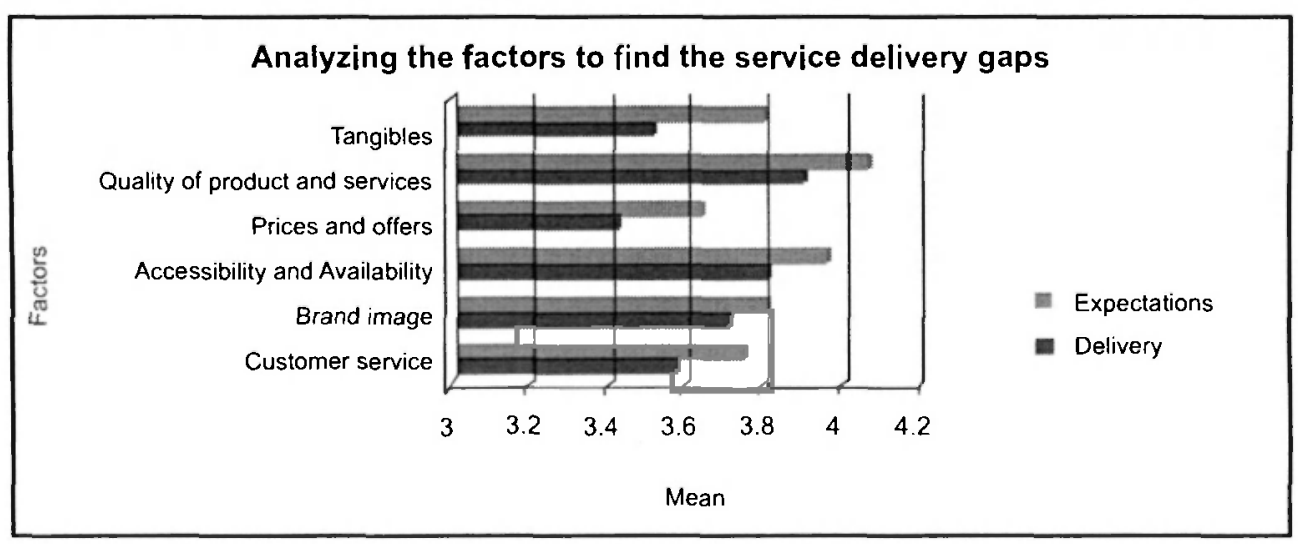


Research Hypothesis: there is significant gap in KMF service delivery.

Paired sample tests were conducted for all the factors to find the differences between expectations and actual delivery. From table 7 it can be seen that for all the factors the difference is significant. This means that there is a gap between expectations and delivery as discussed earlier. The paired sample correlations suggest the associations between expectations and delivery are slightly positive for customer service and accessibility, but the association is not very strong

Table 5. Paired statistics for expectations and delivery

\begin{tabular}{|l|l|l|l|c|}
\hline \multicolumn{2}{|l}{} & Mean & Std. Deviation & $\begin{array}{c}\text { Std. } \\
\text { Error Mean }\end{array}$ \\
\hline Customer service & Expectations & 3.76 & .655 & .018 \\
\hline & Delivery & 3.59 & .623 & .017 \\
\hline Brand image & Delivery & 3.82 & .816 & .022 \\
\hline & Delivery & 3.72 & 1.462 & .039 \\
\hline $\begin{array}{l}\text { Accessibility and } \\
\text { Availability }\end{array}$ & Delivery & 3.97 & .821 & .022 \\
\hline & & & & .020 \\
\hline Prices and offers & Delivery & 3.82 & .765 & .020 \\
\hline Quality of product and & Expectations & 3.65 & 1.359 & .036 \\
\hline services & Expectations & 4.08 & .725 & .019 \\
\hline & & & & .025 \\
\hline & Delivery & 3.43 & .924 & .020 \\
\hline Tangibles & Delivery & 3.91 & .763 & .025 \\
\hline & Expectations & 3.81 & .917 & .020 \\
\hline
\end{tabular}

Table 6: Paired Correlations between expectations and delivery

\begin{tabular}{|l|l|c|c|}
\hline \multicolumn{2}{|c|}{} & Correlation & Significance \\
\hline Customer service & $\begin{array}{l}\text { Expectations } \\
\text { Delivery }\end{array}$ & .381 & .000 \\
\hline Brand image & $\begin{array}{l}\text { Expectations } \\
\text { Delivery }\end{array}$ & .109 & .000 \\
\hline Accessibility and Availability & $\begin{array}{l}\text { Expectations } \\
\text { Delivery }\end{array}$ & .342 & .000 \\
\hline Prices and offers & $\begin{array}{l}\text { Expectations } \\
\text { Delivery }\end{array}$ & .283 & .000 \\
\hline Quality of product and services & $\begin{array}{l}\text { Expectations } \\
\text { Delivery }\end{array}$ & .317 & .000 \\
\hline Tangibles & $\begin{array}{l}\text { Expectations } \\
\text { Delivery }\end{array}$ & .320 & .000 \\
\hline
\end{tabular}


Table 7: Paired Samples Test

\begin{tabular}{|c|c|c|c|c|c|c|c|c|}
\hline & & & Paired & lifferenc & & & $\mathrm{t}$ & $\begin{array}{c}\text { Sig } \\
\text { (2-tailed)... }\end{array}$ \\
\hline Factors & & Mean & $\begin{array}{c}\text { Std. } \\
\text { Deviation }\end{array}$ & $\begin{array}{l}\text { Std. } \\
\text { Error } \\
\text { Mean }\end{array}$ & $\begin{array}{l}95 \% \text { C } \\
\text { interva } \\
\text { Differe }\end{array}$ & $\begin{array}{l}\text { fidence } \\
f \text { the } \\
e\end{array}$ & & \\
\hline & & & & & Lower & Upper & & \\
\hline $\begin{array}{l}\text { Customer } \\
\text { service }\end{array}$ & $D-E$ & .16 & .712 & .019 & .13 & .20 & 8.620 & .000 \\
\hline Brand image & $D-E$ & .10 & 1.594 & .043 & .02 & .19 & 2.456 & .014 \\
\hline $\begin{array}{l}\text { Accessibility } \\
\text { and } \\
\text { Availability }\end{array}$ & $D-E$ & .15 & .911 & .024 & .10 & .20 & 6.096 & .000 \\
\hline Prices and offers & $D-E$ & .23 & 1.411 & .038 & .15 & .30 & 6.029 & .000 \\
\hline $\begin{array}{l}\text { Quality of product } \\
\text { and services }\end{array}$ & $D-E$ & .17 & .870 & .023 & .13 & .22 & 7.367 & .000 \\
\hline Tangibles & $D \cdot E$ & .29 & .990 & .026 & .24 & .34 & 11.070 & .000 \\
\hline
\end{tabular}

\section{Research findings}

Major contribution of the study was the identification of 6 factors of service delivery which can be evaluated. We feel these would influence the framing and evaluation of service delivery activities of KMF Nandini. The factors identified were customer service, Brand image, Accessibility and Availability, Prices and offers, Quality of product and services, Tangibles.

\section{Service delivery gaps}

The analysis of the factors by mean scores suggests that the expectations for all the factors are higher than the delivery. Quality of product and services are the most expected factors by the customers, followed by accessibility and availability. The actual delivery of KMF is slightly below expectations with quality and accessibility being rated higher than other factors. The difference between the expectations and delivery were evident and statistically tested by paired sample tests. The gap is higher for tangibles and prices and offers suggesting company can look into the matter of designing the outlets more effectively. 


\section{Conclusion}

This research explores the significance of identifying the service delivery gaps of any service provider. Effort has been made to study the expectations and perceptions of consumers towards service delivery of KMF Nandini. The study identified 6 factors, which influence service delivery of KMF Nandini. The study also found significant gaps between expectations of the consumers and actual delivery of the company. The findings also suggest the service providers to enhance the effectiveness and efficiency of the service delivery system, which constitute factors of strategic attributes. Such steps will help a lot to achieve corporate goals and objectives. 


\section{REFERENCES}

1. FAO. 1993. Commodity review and outlook, 1992-93. Rome.

2. Gupta, P.R., ed. 1987. Dairy India 1987, p. 9. New Delhi, Rekha Printers Pvt. Ltd.

3. Gupta, P.R., ed. 1983. Dairy India 1983, p. 21. New Delhi, Rekha Printers Pvt. Ltd.

4. Zuvakis, C., Jr. 1979. Economic development: an introduction, p. 227-228. New York, NY, USA, St Martin's Press.

5. S. C. Dhall and Meena Dhall, "Dairy Industrylndia's Strength in Its Livestock," Business Line, Internet Edition of Financial Daily from The Hindu group of publications, 